\title{
BROADENED LAYMAN ACTIVITY SECURED
}

\author{
Results Achieved From Alterations in Methodist \\ Church Polity EnACted IN 1900
}

\author{
By the Rev. R. E. HARVEY \\ Historian Iowa-Des Moines Conference of the Methodist Church \\ VI
}

\section{Des MoINES CONFERENCE ERA ${ }^{1}$-1900-1932}

"Finally, brethren-whatsoever things are of good reportthink on these things."-Phil. IV; 8. "The old order changeth-for God fulfills himself in many ways."-Tennyson.

Des Moines Conference responded to the removal of the time limit from the pastoral term in 1900 , even more deliberately than to the previous extensions to three and five years ${ }^{2}$. This result will be better understood perhaps after reflecting a little upon the spectacular rise and expansion of primitive Methodism, through the rapid rotation of fervid pulpiteers, whose varied talents and methods drew the very widest range of listeners. In their American beginnings the itinerants exchanged places every four or six months. At the organization of the Methodist Episcopal church in 1784, the pastoral term was fixed at one year, with a single reassignment permissive under special circumstances; a rule that obtained for eighty years, although allowed to become suf-

\footnotetext{
${ }^{1}$ The historical series of which this is the concluding article, have appeared in THE ANNALS OF IoWA in the following issues: Sections I and II, Vol. XXV, pp. 192-228 and 282-312; Sections III and IV, Vol. XXVII, pp. 41-61 and 119-150; Section V, Vol. XXVIII, pp. 287-329, a few copies of same yet being available.

2The limit of two consecutive years that a minister might be appointed to the same pastoral charge was increased to three by the $\mathbf{M}$. E. General Conferencec of 1864 ; similar action in 1888 , increased this term to five years; and in 1900 all restrictions were finally annulled. It should be understood by all non-Methodist readers, however, that these appointments are made for but one year at a time, and are renewed from year to year as may be judged best. Appointments of district superintendents were originally fixed at four consecutive years on the same district, with privilege of assignment to another distriet without any interval of time. The limit now consists of a six-year term on the same district, with no continuation of district service until after a six-year interval. See Sections IV and V.
} 
ficiently flexible as to permit the return of successful or popular preachers to former fields after a sufficient interval spent elsewhere ${ }^{3}$.

Inevitably, this procedure, with lapse of time, became grounded in Methodist thought, until probably most of the laity considered that what the founding fathers found so profitable would retain its efficiency for all future time. Furthermore, the practice fostered a craving for novelty, once voiced in brutal frankness to the writer by a parishioner who wanted the ministers moved at least annually, so as to afford him the pleasure of hearing the greatest possible number of them. Nor was this feeling confined to the laymen. There were preachers to whom new pastures and faces were ever greener and more interesting than those already familiar; also callow "boy preachers" who solaced their anguish over past blunders by hoping for retrieval in new surroundings.

For these or other reasons, the average pastoral term, lengthened by only eight months during the era elapsing between its first extension from the two-year limit in 1864 and its final removal in 1900 - the latter action was succeeded by an epoch of such restlessness that the digits indicating the number of each pastor's annual assignment to his parish, resembled nothing so much as a distant line of telegraph poles along the railway, for with rare exceptions, they were all number ones. Of five ministers who completed five-year terms in 1900 , none were reappointed for a sixth; only one-first-year appointee of that session made a six-year record, and it was an additional full quadrennium ere another such was added to the roll; but this last favored brother remained three additional years in the same pulpit, and then to our universal regret, transferred to larger opportunities elsewhere. A very scattering extension of pastorates marked the second decade of this century, and in 1922 a member of this conference rounded out the first ten-year term in the same parish.

3See character sketches of the Rev. Samuel Farlow and some other pioneer clergymen in Sections IV. and V. 
Contrary to all expectations, however, these longer pastorates were not confined to the more important churches, as had been argued in previous discussions. Although the nine-year tenure mentioned above occurred in one of the larger Des Moines pulpits, the first tenyear term was served in a small rural village, and the pastor moved from it to a similar charge. While a fair proportion of all the increasing terms were given to minor congregations, some of them indeed by local preacher "supplies." So slight effect, however, did these occasional increases of tenure have on current procedure, that not until 1927 did the average pastoral term regain the length obtaining under the five-year rule. In 1931 the last separate appointment list of the old Des Moines Conference exhibited assignments as follows : for first year, 60 ; second, 77 ; third, 42 ; fourth, 21 ; fifth, 4 ; sixth, 3 ; seventh, and eighth, one each; with general average of two years, two months and seven days.

The depression conditions of the thirties, accelerated by the drafts for chaplain service in World War II, so operated that in the pastoral assignments for 1944-45 over twenty-five per cent were for the fourth year and upwards; viz: for first, second and third years, 197; fourth year, 31 ; fifth year, 21 ; sixth year, 11; seventh and ninth years, 3 each; tenth year 2 ; and one each for the thirteenth, fourteenth, eighteenth and twenty-fourth years-seventy-five in all, who were distributed pretty evenly among small, medium and large congregations. It is interesting to note, that the minister in this list assigned for the thirteenth year was the same who first achieved a ten-year term, and the two parishes virtually adjoined one another, also, that the longest term of all was for the eighteenth year of the second term served in a very minor field, by a devoted "accepted supply pastor". Also it is of interest to find that despite lengthening pastorates, the general average of service, three and one-third years, is less than three times the tenure enjoyed eight decades previously under the two-year 
limit, the exact equation standing this-1860-64, fifteen months, 1944-5, forty months; conclusive evidence that neither Methodist preachers nor people are stampeding into any sort of settled ministry: not at least in the south half of Iowa.

\section{SLOW to Adopt Changes}

The other radical alterations in church polity enacted in 1900 endured like inertia with that pertaining to pastoral service; the principal seeming result of equal representation in the governing body of the church being a little wider diffusion of acquaintance with denominational objectives, by reason of the greater number of laymen brought in contact with legislative action on various subjects. A Lay Association was formed in 1910, designed to encourage Conference attendance. At its three annual sessions intervening between Lay Electoral Coferences ${ }^{4}$, it functioned rather spasmodically, but was revived from time to time, becoming a helpful advisory adjunct of the ministerial body, and an excellent training school for admission of laymen on equal footing with their pastors, with whom they integrated so smoothly as to occasion wonder that the practice had not been adopted long before.

Even less visible results accrued from granting female eligibility to Lay Conference membership. In the eight General Conferences held during the period now considered, of forty-eight lay delegates from Des Moines Conference only six were women, and one of these was an alternate seated in place of a man unable to attend. However, factual possession of the right lent impetus to the demand that legal status be awarded the increasing number of women preachers, who as evangelists or temperance lecturers were gaining easy access to Methodist pulpits; a demand much accentuated by deaconess employment as assistant and mission pastors, and finally materialized in 1920, by authorizing the licensing of female local preachers. This action was followed im-

\footnotetext{
¿See "Lay Electoral Conference," at the end of Section IV and beginning of
Section V.
} 
mediately by the appointment of a few "elect ladies" to "supply charges" some of the earliest of whom are still in the ranks, with advanced prestige through admission to local orders in 1924, and later on inclusion in the auxiliary ministrial body of "Accepted Supply Pastors," entitling them to appointments and pensions on equal terms with their masculine colleagues. But, thus far, all proposals to receive females in the classes for "admission on trial" to conference membership have been emphatically denied ${ }^{5}$.

The spirit of reconstruction once let loose proceeded to modify other phases of Methodist procedure; encouraged by the voluntary retirement of then senior Bishop Stephen N. Merrill, the General Conference in 1904 relieved several of his associates from executive duties, and fixed a retirement age limit for the entire episcopal officiary. Four years later by a yet more drastic action they proceeded to retire for inefficiency a bishop lacking some years of the deadline.

Then came transition from the yearly presidency of conferences (some defects of which are set forth in Section $\mathrm{V}$ ), to the area system of assigning each bishop a four year supervision of a contiguous group of conferences. During the experimental stages of this plan, the resident bishop presided over sessions in his area alternate years. This procedure served as a protection against possible abuse of authority, and a means of correcting errors of judgment; a provision for which Des Moines Conference had one occasion of thankfulness, when wiser judgment reversed arbitrary decrees of a wouldbe lord over the church's heritage. This precaution was reduced in time to one year in the four; then a return for a second term was allowed where satisfactory conditions prevailed, a regulation that accorded Omaha Area (Iowa and Nebraska), the exalted priv-

\footnotetext{
${ }^{5}$ The unification of 1939 brought into the new Methodist church a limited number of feminine members of conference in full standing, belonging to the former Methodist Protestant Church, and who did not lose their ministerial positions in the reorganization. These in this Conference are assigned as co-pastors with their husbands. The number of ordained female "accepted supply pastors" slowly but
} 
ilege of eight years association with the ablest, wisest, most brotherly and approachable member of the episcopal board this writer ever contacted. Coming to us fresh from great accomplishments in three vast overseas mission fields, Homer Stuntz gave us the best fruits of his ripest years, and then passed directly to ampler realms of service than earth can afford.

By change of area boundaries South Dakota replaced Nebraska as Iowa's teammate, with headquarters in Des Moines; realized after fifty years the writer's objective in his first adventure into denominational politics, when he presented in the Electoral Conference of 1887 a resolution memorializing the General Conference to make Des Moines an episcopal residence.

\section{Negro Bishops AUthorized}

And now I crave permission to relate an episode in episcopal evolution that only claims space in this chronicle because it transpired in the Des Moines Coliseum during the General Conference of 1920, but is worthy of record as marking an extension of minority rights, as significant in Methodist history as the granting of complete independence to the Philippines is in American and world history.

Taking a long backward glance let us note that the religious and educational work begun by northern Methodism among the freed slaves at the close of the Civil war, so prospered that at the century end, one-tenth of the Methodist church membership were of African descent, having separate parishes, conferences and institutions of learning, staffed largely by ministers and educators of their own race, from among whom they sent to the high councils of the church parliamentarians, who held their own with the ablest dignataries of Nordic extraction.

Laboring, as this colored minority did, alongside organizations of Negro Methodists who flaunted their independence of white overlordship, very naturally there 
evolved a demand for leadership of their own race, a desire shared by other minorities consisting of our rapidly expanding foreign mission fields; demands supposedly met in 1904 by a constitutional amendment authorizing the election of Bishops for Races and Languages.

Securing the right was one thing, enjoying it decidedly something else. In three General Conferences, composed overwhelmingly of white North American Methodists, Negro episcopal candidacies were launched with much Caucasion approval, only to flicker out amid the keen competition among white aspirants, leaving an increasing volume of bitter frustration, that threatened serious defections from our colored membership, assailed as they were by incessant invitations to affiliate with churches of the same complexion-a situation rendered more complicated by the barrier this Negro membership always interposed to any proposed reunion with the M. E. Church, South, where aversion to anything resembling racial equality was as rigid as the Chinese wall.

As a solution of this problem a resolution was submitted in the General Conference of 1920 providing for the election of two Negro Bishops on a separate ballot. Then ensued a battle royal of debate in which opponents of the measure condemned it as an unholy recognition of the color line, to which an eloquent black man responded with unanswerable logic, saying (in substance) : We deal with conditions, not theories; the color line is here and will remain for a long time to come; no white clergyman who has spoken against this resolution ever expects to be pastor of a colored congregation; none of you white laymen will ever have a Negro as pastor; give us this opportunity to develop leadership and you will do more to wipe out the color line than by passing dozens of flowery compliments on the advancement of the exslaves; and this is the only way by which we may gain this opportunity. Every previous effort to obtain a Negro bishop has failed, because our white supporters, 
in the pinch, desert our candidate for their own. Now, we do not censure you for this, since it is exactly what we ourselves would do, were circumstances reversed. We hear fears expressed that our black bishops will make trouble by demanding the presidency of white conferences, but with twenty such bodies longing for the sight of a black face in the president's chair, we promise we will keep two men so busy that they will have no time to embarrass you with their claims. Some tell us that we should cast in our lot with the great Negro Methodisms now negotiating union ${ }^{6}$. I will not say that I might not like membership in such a church, but I do say that you have no right to tell me that I must belong to such a church, at the sacrifice of all association with the very highest and most enlightened type of Christian civilization the world has ever seen."

On that note the discussion ended; the vote was taken, and the presiding officer amid rising tension declared the measure adopted by a triumphant majority, and immediately announced a fifteen minute recess, just ahead of the release of a flood of pent-up emotion which would have thrown all camp meeting ecstacies or Salvation army halleluyah times into the shade! The colored delegates and spectators in the galleries shouted, laughed, wept, sang, clapped and shook hands, pounded each other's shoulders, all at once, and some of their white allies were not far behind in hailing the new era. Followed two days of intensive but quiet electioneering, and a single casting of ballots elevated two eminent Negro clergymen into the highest office in world-wide Methodism. One of them was given an area in the deep south, the other in darkest Africa, and both adorned the episcopacy and the cause of Christ with a fervent faithfulness that greatly helped smooth the way for the acceptance by southern Methodists of a unification plant retaining the black minority within the fold, as captains

\footnotetext{
"The African M. E. Church, the Zion Afriean M. E. Church, and the Colored M. $\mathrm{E}$. Church, then claiming a combined membership of about $2,000,000$, were engaged at that time in negotiations looking toward organic union; an objective as yet never realized.
} 
of their own souls. The only repercussion of this epochal event upon this conference consisted of the twice repeated effort of an over-zealous brother to have a colored bishop invited to preside in this body; proposals quietly laid aside in committee as often as made.

The unleashed spirit of innovation took up the subepiscopal office in 1908, when the Rev. James M. Buckley, reversing his forty-year old conservatism, scored the last of many legislative victories, by securing alteration of the ancient title "Presiding Elder" to "District Superintendent," a change perhaps indicative of the shift of emphasis from oratorical talents to executive efficiency as chief requisites in the office; no change of district administration attended the change of title, but with the systematic supervision of the area system, there crept in a tendency to revive the "Continuing Cabinet" practice ${ }^{7}$, that seemed destined to permanency with the removal of the time limit on the office in 1920 . The only effect in this conference was the continuance of one incumbent for eight years, while directing some district financial operations. In some large eastern conferences however, politically-minded characters dug themselves into the obstruction of both episcopal prerogative and district preferences in such fashion that in 1924 the limit was restored, with the further safeguard of restricting appointments thereto to six years in any given twelve. A determined effort put forth at the same time, by the so-called "insurgent pastor" element, to declare the office elective rather than appointive, was side-tracked by parlimentary tactics, so that it never came to a vote. Renewed four years later, it was decisively and finally beaten. In recent years, when filling district vacancies, a sort of Gallup Poll of pastoral preferences has been taken by the area bishop, that seems to answer every purpose of an election without incurring the possible frictions of rival candidacies.

\footnotetext{
TThe "continuing cabinet" era of Des Moines Conference-see Section V-was a period when a group of able and astute preachers assisted one another to remain in the presiding eldership for a period of some twenty years or more, and operated by shifting these parties from some district to another as their disciplinary terms expired, without any interval between terms.
} 
The last innovation of this epoch claiming attention removed one of the most ancient Methodist usages from the scene. The primitive Wesleyan societies in England required for admission only "the desire to flee from the wrath to come, and be saved from one's sins" yet imposed upon all so received a six months waiting period, in which to prove their sincerity by strict observance of certain rules of conduct, before becoming full members. On the far-flung circuits in America, the probationary practice proved invaluable, affording opportunity for devout, experienced class leaders to instruct and ground in faith and works the converts awakened by the pastor's evangelistic appeals during their monthly rounds. In course of time, however, the shrinkage of these immense parishes into single congregations with corresponding increase of church services and pastoral contacts appeared to render the probationary requirement superfluous, and in 1912 it was replaced by a public profession of faith as sole requirement for reception into full membership; although a training period is still used in preparing for admission the baptized children of the church, and the ingatherings of Decision Days and like means of grace.

\section{Establishment of A Hospital}

Far swifter reactions than any described above attended the inclusion of human suffering in the Des Moines Conference program; for the new century was barely sixteen days old, when Iowa Methodist hospital opened its doors, with a fifty bed capacity for patients, and lodgings for nurses ${ }^{8}$. All doubts as to the need of such an institution were dissipated eight months later

\footnotetext{
${ }^{8}$ The hospital enterprise was initiated by Theodore Gatchell, insurance exceutive, who called a group of laymen and ministers together at a dinner and broached the idea. Subsequent meetings of the group shaped an association for this purpose. Besides Mr. Gatehell, Major Bidwell, Leroy M. Mann, Edward D. Samson, William H. Arnold and other prominent laymen, were identified with the project, all of whom have long ago passed on. But, of the clergy, the Rev. Amos E. Griffith, then pastor of Wesley Methodist church, last surviving member of this association, lived for almost half a century to note the results of their deliberations. See Section V, for further details. It is only proper to add that through the influence of L. M. Mann, Mr. Callanan was induced to cancel a large portion of the purchase price, thus repeating the generous action by whhich this Quaker born, non-church going financier helped old Fifth Street M. E. Church out of the slough of despond some forty years previous to this later philanthropic donation.
} 
when the next conference session heard the report of 329 patients treated, one-fourth of them charity cases; with a rising tide of contributions both in money and supplies flowing in steadily in response to the impassioned appeals of the Rev. John F. St. Clair, who as financial agent for the hospital, staged a statewide canvass among Methodists (and probably some others), with such good effect that besides paying debts incurred in launching the institution and operating costs, there was erected during the next five years an additional wing, three stories high, $40 \times 100$ feet in size, and a separate building for a nurses' home. From the completion of these tasks Dr. St. Clair was called to like performances in Kansas City, and elsewhere, finally passing away in the harness as Bishop Stuntz's financial assistant for the Omaha Area?.

Scarce were these enlarged facilities in use than ampler expansion became imperative; the nurses' home was extended sufficiently to house and train eighty occupants, and a second wing added to the main building, five stories high, 50x100 feet in size, these improvements completed and dedicated in 1912, soon followed by replacement of the old college edifice with a new central structure, bringing the hospital to its present status, accommodating about 250 patients, besides maternity and operating wards, chapel, offices and medical dispensary.

As to benefits conferred the following exhibits drawn from annual conference reports will testify. That for 1910 credits the home with having graduated, from the beginning - seventy-five registered nurses, with as many more in training; of over 12,000 patients received only a little over nineteen per cent of Methodist faith, and probably half of the remainder were of no church at all, since neither credal nor racial lines were drawn among suffering applicants. About one-fourth of all were admitted free of charge, or at greatly reduced rates, the

9See character sketch of Dr. St. Clair in Section V. 
expense of their care being computed for a single year at $\$ 27,000.00$, most of which sum represented the gratuitious services of the medical and surgical staffs.

Ten years later the records give for these first two decades of operation a total of 153,100 patients received; 162,000 dispensary customers served, and relative amounts of charity work performed as already indicated. No detailed accounts appear in conference reports for the last dozen years of this chronicle, except to note that once or twice the expiring year had surpassed all prior records, but the quality of work performed then and since is sufficiently attested by the placing of that noble contribution to child welfare, the Blank Memorial hospital under the auspices of Iowa Methodist; and the yet more recent pledging of a round million for the final completion of this great House of Mercy.

Space forbids any proper appraisal of the band of field agents who sacrificed home comforts and associations and went forth for more intensive gleanings of fields made narrower by the establishment of other Methodist hospitals within the state, not to mention various denominational and private institutions springing up on every hand; the spiritual care bestowed upon the unfortunate claims recognition. At first city pastors assumed these duties in addition to their parish obligations. When multiplying needs required continuous service the Rev. Asahel E. Thornbrue ${ }^{10}$ was employed as chaplain, who in 1918 was succeeded by the Rev. Dilman Smith, then member of Upper Iowa Conference, but afterward transferred to this. Besides comforting the afflicted and guiding the penitent, he labored valiantly in financial and office tasks, until overtaken by the infirmities of age, when the present incumbent, the Rev. Merle Gable, took over the spiritual care of the multitudes stricken in body. All three of these and their future successors, along with the host

${ }^{10}$ See character sketch of the Rev. Isabel E. Thornbrue, in Section V. 
of men and women who have freely bestowed on this Christlike benevolence, money, food, fruit, room furnishings, time, thought and prayers, must await their full measure of compensation until the King shall say unto them, "Ye blessed of my Father! I was sick and ye ministered unto me."

And now we recognize an enterprise originating in the minds and hearts of a devout couple who were active in promoting its usefulness until no longer able to carry on. Mrs. A. E. Griffith was the daughter, sister, wife and aunt of a group of seven Methodist preachers, and identified with the Women's Home Missionary Society from its inception; who also took a prominent part in sponsoring the deaconess movement on its appearance in this conference, helping obtain its first headquarters in Des Moines, afterward securing for this purpose the property at 1155 Ninth street in Des Moines, named in honor of its chief financial backer, "The Bidwell Deaconess Home and Bible Training School," where it developed until the lot afforded no room for further expansion of the plant. Then she purchased, with a down payment of a thousand dollars, an unused school building at Tenth and Pleasant streets and offered it to the Conference Deaconness Board as according greater facilities for their growing work. Some time later, on becoming a trustee of the National W.H.M.S., Mrs. Griffith enlisted that body in the replacement of the old school house by the fine structure adorning that site, and renamed "The National Bible Training School." Here Dr. Griffith devoted the later period of his active ministry, serving variously as field agent, teacher, dean and superintendent, one of his most notable achievements being the securing theological degrees for graduates of the Training School, upon completion of a year of study in the Bible College of Drake University. Mrs. Griffith also taught in the Training School until completely broken in health, and her memory is perpetuated 
by the inscription of her name above the chapel door in what is now known as "Esther Hall," utilized as a home for business and working girls ${ }^{11}$.

\section{RETIREMENT RELIEF Stabalized}

And next, reverting again to the century end, let us resume consideration of the conference claimants, who were increasing so much faster than relief funds that their allowances in 1900 were barely forty-four per cent of those granted thirty years previously, although twofifths of all were passed over as able to get along without help, such grants being then allowed solely on the basis of necessity. By this time the Preachers Aid Society was chiefly under direction of elderly men, who very naturally disturbed by conditions that soon would affect themselves, enlisted the Rev. Fletcher Brown, the most successful money getter in the conference, in a five-year campaign to add $\$ 50,000.00$ to the Endowment Fund, then totaling $\$ 16,833.00$, producing income of less than a thousand dollars per annum. Using the tactics by which he had placed the affairs of Simpson College on easy street, Dr. Brown within the period assigned secured pledges for $\$ 60,999.00$, the installment payments on which, besides meeting his salary and expenses, raised the fund to above $\$ 20,000.00$, yielding $\$ 1,275.00$ income in 1905 . His earnest representations of the distressed situations of many worthy veterans produced a more immediate reaction that increased the "Fifth Collection" 12 to a point that advanced the pension average fifty per cent above the 1900 figure, whereby three specially deserving clergymen were allowd $\$ 300.00$ each, and one widow received $\$ 200.00$. Moreover, the

\footnotetext{
11This information relative to Mrs. Griffith's activities was derived from correspondence with Dr. Griffith, and intended for use in writing a centennial History of Des Moines Methodism, that due to a severe surgical operation and long hospitalization, never materialized. It is a pleasure to have this opportunity to give the data historical publication.

${ }^{12}$ Fifth collection, so-called because at the time the care of superannuated preachers, widows and orphans of preachers, was made a legal requirement by church law. There were but four benevolent causes claiming support, missions, bible solaw. There were but four benevolent causes claiming sure tour were supposed to be taken ciety, education and Sunday school union. These four were supposed to collection for conference claimants between the last quarterly meeting and the annual conference, but schedules very often got all tangled up, and if any collection suffered or was overlooked, it was likely to be the "fifth."
} 
stewards for the first time, reported the total of claims filed $\$ 12,000.00$, almost double the sums at their disposal, and recommended that this amount be apportioned among the several parishes for the ensuing year's collection; an action so productive that by 1907 the claims were paid seventy-five cents on the dollar.

Meantime Dr. Brown's agency was extended for a second "five-year plan," during which his interest became largely absorbed in a proposed Home for Retired Ministers, and widows of preachers for this city rental properties valued at $\$ 30,000.00$ were pledged, on condition that an equal amount be raised from other sources for this purpose. On attainment of this goal a spacious Indianola residence was purchased and named "The Francis Home," in commemoration of Daniel Francis, original proponent of the plan, and donor for the same. The management and maintenance of this institution interfered so seriously with promotion of the Endowment Fund, that, although his agency was extended to a third five-year term, at Dr. Brown's accidental death in August, 1912 , its total of $\$ 41,478.00$ equalled only one-half of the contemplated advance from the 1900 figures. At the same time the Francis Home was reported in prosperous condition, housing twenty-four guests with room for as many more. But, with loss of Fletcher Brown's insistent promotion, its affairs fell into such confusion that in 1914, the conference ordered the institution sold, and the earnings of its proceeds devoted to the relief of specially destitute cases among the claimants. The financial collapse of 1930 left much of this money in the frozen assets of suspended banks, where it suffered like shrinkage with other deposits, and the residue recovered has been now applied to the recently launched old Peoples Home of Iowa-Des Moines Conference at Des Moines.

The church legislation of 1908 , replaced the meagre dole previously granted necessitous cases, by a pension system based upon length of ministerial service, inclusive, 
regardless of worldly circumstances, of all retired ministers, and the widows and orphans of ministers. The operations of the new plan are equitable and clear. Having fixed upon thirty-five years as the general duration of effective service by Methodist clergymen, it was ordered that retired ministers with such record be entitled to pensions equalling one-half the average cash salary paid members of the same conference, with annuity rates for longer or shorter periods, gauged accordingly. Thus, assuming that the average of salaries paid in Des Moines Conference at the time of this legislation was $\$ 1,050.00$ per annum (it actually was close to that sum), $\$ 525.00$ divided by the above years, fixes the annuity rate per annum at $\$ 15.00$ as the amount granted for each year in the effective relation, be they many or few. Fifty per cent of this rate, $\$ 7.50$, constitutes the widow's allowance for each year of her parsonage life; and twenty per cent of the father's total claim was allowed to each orphan under sixteen years of age. To be explicit, assuming that a minister having the above record, did not marry until two years after joining conference on trial, giving his wife thirty-three years as his companion in the effective ranks, her annual pension at his decease would be, $\$ 247.50$, while each orphan under sixteen would receive $\$ 105.00$, twenty per cent of the father's claim. In case the years of service did not furnish a pension sufficient for comfortable support, provision was made for special assistance ${ }^{13}$.

\footnotetext{
1sThe subjoined listed exhibits will best assist in understanding the very moderate change immediately wrought in shifting from necessitous relief to annuity pensions, except as to numbers included in the latter plan. At least seven ministers and two or three widows relinquished their pension claims in 1911, in favor of those less well supplied with resources than themselves.

Exhibit A. 1907 Preachers pensioned, 33 ; amount distributed, $\$ 5,277.00$; average allowed, $\$ 160.00$, lacking a few cents; maximum grants, four received from $\$ 300.00$ to $\$ 325.00 ;$ minimum, ten were rated below $\$ 100.00$. Widows pensioned, 43 ; amount distributed, $\$ 4,342.00$; average paid, $\$ 101.00$; maximum grant, $\$ 200.00$, one; minimum, ten below $\$ 100.00$. Orphans allowances were included in mother's drafts, without indicating size of same.

Exhibit B. 1911. Preachers pensioned, 56 ; amount distributed, $\$ 9,432.00$; averare paid, $\$ 168.50$; maximum, $\$ 491.00$, one; $\$ 400$, one, both of which grants, and three ranging from $\$ 300.00$ to $\$ 325.00$, were greatly augmented from special funds, as likewise were a large number of others. Minimum grants, sixteen rated below $\$ 100.00$; highest payment for annuity years alone, $\$ 291.00$, and only two others rated $\$ 200.00$ or more for service years. Widows pensioned, 46 ; amount distributed, $\$ 4,689.00$; average paid, slightly below $\$ 102.00$; maximum allowed, $\$ 200.00$, two; minimum, rated at $\$ 50.00$, or less, six received special grants; six having children were allowed sums ranging from $\$ 10.00$ to $\$ 75.00$ governed by deceased parents' years of service.
} 


\section{CHURCHES ASSUMED RESPONSIBILITY}

Moreover, to assure funds sufficient for this very great increase of support, the pension apportionment was made part of the parish salary budget, along with the claims of district superintendents and bishops, and all four items prorated together, sharing in any deficit, proportionately, and the three "overhead items," as they might be called, were fixed at certain percentages of the pastor's salary; which at the date stated were respectively, for Episcopal Fund, two and one-half per cent; District Superintendents, seven and one-half per cent, and Pensions, five per cent; a total of fifteen per cent, yielding on the salary basis above assumed $(\$ 1,050.00)$, and additional $\$ 157.00$ to the ministerial budget of the parish. This would have spelled an immense increase to the pensioners, save for the fact that the inclusion of all veterans and widows, heretofore adjudged as not necessitous cases, so lengthened the pension rolls that notwithstanding the generous relinquishment of their claims on the part of a number of worthy men and women who felt in no need, the amounts paid in 1911 when the new plan was fairly in working order, were little if any advanced from payments in 1907, the last year of the old plan ${ }^{14}$.

It is only proper to say, however, that for an entire decade, every proposal by the stewards to raise the five per cent apportionment for pensions to an adequate figure were rejected by the conference, lest a heavier impost might provoke lay opposition, in which the entire salary budget might suffer; the immediate effect being to keep the 1911 annuity rate at $\$ 5.75$, instead of $\$ 15.50$ as it should have been, imposing on the stewards a tedious

\footnotetext{
${ }^{14}$ Some nameless homespun philosopher once upon a time enunciated the following, "Verily, he that tooteth not his own horn, shall find said horn untooted for lack of tooters to toot for him !" This maxim must be an answer as the writer's excuse for a little tooting, since few survive who might toot for him. Of the aforementioned improvements in pension procedure, the following originated with himself; payment by check instead of bank draft; creation of the sustentation fund (See foot note 15) ; extension of orphan's pensionable age to eighteen years ; initiation of widows' and orphans' claims at date of bereavement; requiring certificates from non-resident pensioners annually; and extension of pension rights to supply pastors and their dependents in pension distributions. This latter was very last motion made by him for conference action before asking for retirement. Some of these measures were adopted over serious opposition, but all have long ago been embodied in Methodist church law, besides some other matters he failed to secure..
} 
retention of necessitous calculations, somewhat compensated by their relief from the old time obnoxious and irritating inquisitions into personal affairs, productive of many a headache.

Within the years following the Reaper Death made havoc among pensioners of long service, and steadily rising salaries swelled pension receipts; so that in 1915 , after six noble brethren, entitled to large grants, relinquished their claims, a rate of $\$ 10.00$ became possible, giving forty-two ministers awards averaging $\$ 245.00$, with the maximum at $\$ 510.00$, and only one below $\$ 100.00$. Although the death of husbands increased the widows to sixty-three-one of whom waived her rights-they received allotments averaging $\$ 133.75$, the highest being $\$ 280.00$ and several at $\$ 50.00$ or less.

The 1916 General Conference slashed the men's pension grants by ten per cent, in raising the widow's portion to seventy-five per cent of the deceased husband annuities; but unintentionally rendered compensation by electing to the episcopal office, the Rev. Matthew Simpson Hughes, who, in his one administration of Des Moines Conference, on discovering that the five per cent apportionment was totally inadequate, refused to allow a vote on the question until this figure was raised to twelve per cent. This action, which contrary to all expectation, was accepted by the laity without a murmur, coming as it did at the peak of World War I prosperity. It was considered only another small item in the unprecedented boosts of church-and all other-expenses. The new apportionment never quite realized its objective, but doubled pension assets so that 1920 minister's grants averaged $\$ 498.00$ and one reached $\$ 888.00$ earned by forty-eight years faithful service; the minimum grant being $\$ 120.00$; while the widows enjoyed averages of something over $\$ 300.00$. Of fifty-four retired ministers, four relinquished their pensions and only four requested special assistance. There were seventy-one widows, whose annuity rate of $\$ 13.50$ yielded to one with service 
record equalling that of the male pensioner mentioned above, an allowance of $\$ 648.00$, while there were two, widowed after but two and three years respectively, whose claims of $\$ 27.00$ and $\$ 41.00$ were increased to $\$ 50.00$ each, from special funds. Only two more, because of similar brevity of married years, were rated below $\$ 100.00$, and fifteen in all enjoyed special grants, some of which were for funeral expenses of departed companions. Five children of three bereaved mothers, divided $\$ 318.00$, an increase of one-fifth of previous grants, due to General Conference action of that same year, raising their pension claim to twenty-five per cent of their father's rights; with the added benefit of being continued two years longer-to eighteen years-covering the most expensive period of the high school course. Both of these improvements were adopted on recommendation of a steward's convention held in 1919, during the Methodist Missionary Centennial in Columbus, Ohio.

From this pleasing retrospect we pass to 1927 , when this scribe shifted status from distributor to recipient of pension benefits. Then, due to increasing list of pensioners without relative advance of receipts, the annuity rates receded a little from the high water mark of $1920,(\$ 18.50, \$ 13.50$ and $\$ 4.50)$, and stood at $\$ 16.00$, $\$ 12.00$ and $\$ 4.00$, respectively, for the three classes of beneficiaries. This recession was carried farther by the beginnings of depression, as shown by the last separate report of old Des Moines Conference in 1931, when they stood $\$ 14.00, \$ 10.50$ and $\$ 3.50$, yielding to ministers, averages of $\$ 406.50$ to widows, $\$ 256,70$, while two orphans whose father had served thirty-four years received $\$ 119.00$ each, and one with twenty-seven years claim, was awarded $\$ 94.00$.

As concrete examples of pension dealings at the date just given we may note that the highest minister's pension was $\$ 675.00$, widows, $\$ 402.00$ and three orphans $\$ 104.00$ each; also it should be noted that only six requests for special aid were made by women, the largest 
of which was for $\$ 177.00$, burial expenses; the next largest, $\$ 136.00$, for the care of a crippled, invalid daughter. Although one brother received merely $\$ 121.00$, only three men asked for special relief, proving clearly that the veterans of the Cross and their bereaved dependents were enjoying a degree of comfort undreamed of by their predecessors of a generation previous.

The lag of funds behind growing requirements in the middle nineteen twenties, mentioned above, was largely occasioned by discontinuance of the endowment campaign shortly after Fletcher Brown's death, which was not renewed until 1923. Then by conference vote other proposed financial projects were set aside in favor of this one, which was finally launched in 1925 , under directions of the Rev. Edgar M. Evans, who, ably assisted by almost the entire pastoral corps, made a canvass that raised the fund in 1931 to about $\$ 135,000.00$, yielding an income of $\$ 5,466.00$, which further exertions have advanced until at this writing it bids fair to equal the million dollars estimated by this writer, a quarter of a century ago as necessary.

\section{Progress in Pension Procedure}

A review of pension procedure during the writer's thirty years connection with that branch of conference administration will be in order. When first assigned to this duty in 1897, the stewards and other standing committees were appointed, without prior intimation, Wednesday noon, at the close of the opening session of conference, leaving us only the interval between other meetings for receiving and considering claims, with no information as to monies at our disposal before hearing the conference treasurer's report on Saturday morning. Then the preliminary list of grants was prepared to be read in open session and opportunity given for compliants, of which there were always plenty, sometimes expressed in terms better forgotten than described, when aged men allowed the sense of their own wants to completely obscure the necessities of others, or jealously charged 
favoritism in allowing larger awards than theirs, to some brother of whose situation they knew nothing. Rendering honor where honor is due, let it be said that no widow ever came before us with either claims or complaints; for, aside from a very few polite inquiries, by mail, concerning diminished grants, the ladies accepted what we had to give, with resignation if not gratitude. Often with Monday morning came information of new retirements, requiring the revising of our entire list of allowances; and then, as payments at that time were made by bank draft, our treasurer and some harrassed bank official must needs rush through the preparation of these for distribution in open session just before final adjournment. On call of the bishop, the names and amounts were read out, the drafts handed to pensioners present, and volunteers asked to assume responsibility for delivery of the precious slips to absentees-a somewhat dramatic procedure, later displaced by less spectacular methods.

In time came corrections whereby stewards were appointed a year in advance and then for terms of three years, and so staggered as to assure the board an experienced majority at all times. Payment by check instead of draft simplified the treasurer's task, and use of mails dispensed with personal deliveries; while adoption of the annuity pension plan brought relief from the embarrassing investigations of personal possessions, income and other private affairs, with most of the unreasonable arguments of disappointed claimants. Likewise, the original practice of deferring pension grants until a year after retirement gave way to immediate payment; but the unfair custom of letting widows and orphans of pastors dying in midyear wait until the ensuing conference session before obtaining relief, continued until the General Conference of 1924, made their just claim take effect upon the bereavement that robbed them of home, support and supporter at one fell swoop. 
The same body required pensioners living outside the bounds of their own annual conferences to file annual certificates of good character and loyal church affiliations, with the secretary of the conference in which they held membership, as a condition of being kept on the pension roll; and similar information to be supplied in cases where minister's orphans were adopted by nonministerial families; thereby plugging leaks through which a few covetous souls were siphoning unrighteous gains; instances fortunately rare, but where known occasioning propaganda hostile to the entire pension system.

Action taken by Des Moines conference in 1927, extended pension rights to that worthy and little appreciated class known as "supply pastors", and their dependents, having the record of fifteen years of ministerial service, a recognition since made churchwide.

When state legislation directed all denominational governing units to incorporate, Des Moines Conference installed its stewards as trustees. This occurred about the time that great tides of migration elsewhere began closing country and village churches in this area; consigning them by both state and church law into custody of the trustees, with instruction for sale of the same, the proceeds to be held in trust for five years, pending possible reorganization of the defunct societies; after which said monies lapsed to church possession, to be applied according to original intentions in as close proximity to the former site as conditions warranted. On the very few like occasions during the era of expansion, such funds were turned over to nearby parishes, or doled out for church and parsonage improvements; but with larger amounts accruing or in prospect of accrual, such monies, both lapsed and in trust, were constituted as a revolving loan fund, for assisting church enterprises. Probably the most important of these was the second loan so made, whereby the conference acquired title to the magnificent site at Ames, across Lincoln highway from Iowa State 
college campus, whereon stands Ames Collegiate church and the Wesley Foundation. Provision was made that one-half of this fund might be lent to needy congregations free of interest, and upon its accumulation to a total of $\$ 10,000.00$, the interest earnings thereof might be donated to weak or newly formed parishes for terms of not more than five years; by which various uses more struggling societies have been assisted out of severe straits than we have space to ennumerate ${ }^{15}$.

\section{When IOWA Lost PopUlation}

The mounting prosperity featuring the early decades of this century, while it boosted church budgets and benevolence collections, also inflicted serious losses on the church life of southwestern Iowa. Thousands of young and middle-aged Methodists lured by the glamour of cheaper land, exchanged super-valued Iowa acres for larger holdings, scattered all the way from the Rio Grande to Canada's wheat fields, and the orange groves of California; and thousands of older people rented or sold the farms they had made out of the raw sod, either migrating to milder climates, or settling down in the idylic ease of retired farmers in the larger towns. While these movements were depleting the country churches, large numbers of small-town magnates, such as merchants and bankers, were by the kindred enchantment of easier and larger gains drawn into search for the-sometimes mythicalrainbow ends abounding in the cities; and the latter in turn contributed their full quota to the expanding metropolitan areas of the nation.

All too frequently the vacated farms and dwellings were taken over by non-church goers, while improved highways, automotive transportation, and movie palaces turned Saturday night, from dusk to the early morning hours, into the busiest part of the week for business and pleasure; and under all these impacts Sunday school and

${ }^{15}$ Said revolving loan fund consisted at its inception of about $\$ 5,000.00$ and during its first year made three different enterprises possible. It has now grown to over $\$ 25,000.00$, and continues its useful policy. Called at first the "sustentation fund," it is now more appropriately known as the "abandoned church fund." 
church attendance waned, flickered, vanished, and the unchurched newcomers were quite generally overlooked by a ministry largely unfamiliar with the crusading zeal that drove the pioneer clergy to the outmost edge of settlement, in search of the most recent homesteaders.

Thus beset, it is not strange that membership rolls of the most exclusively agricultural district of the conference remained almost stationary for an entire decade, and the nineteenth century exultant reports of new parishes established, and new houses of worship erected, faded into what were at first apologetic, but later mere matter of fact, requests for permission to sell abandoned sanctuaries and vacated manses. The full effects of the entire recession is indicated by noting that of 448 church buildings reported in 1900, there remained 320 in 1931 . Not so serious however was the decline of pastoral charges, 206 versus 210 .

This was due to a return to the primitive circuit system, on a pattern differing materially from that of pioneer days, when every sizeable hamlet and many strong country church headed charges numbering from two to a dozen preaching places, according to ability to support a preacher. The modern circuit is more likely to be composed of two or three of those former centers of operations, to which pastoral attention is chiefly confined, leaving the open country more and more neglected, for similar losses befell other denominations, and their deserted fields frequently far out numbered those of Methodism.

Lest it should be inferred, from this lament over past glories, that Des Moines Conference Methodism was on the way out, let it be said that the transitional movement was more one of concentration than retreat, as can be demonstrated by comparative ten-year exhibits of lay membership statistics. In 1901 , there were 50,$826 ; 1911$, 54,$384 ; 1921,69,513 ; 1931,76,100$; of which last number, 3,433 were received during the preceding twelve months, two-thirds of them by profession of faith; evidence that 
the science of soul winning still bulks large in Methodistic curriculums. Also it is definite and further evidence that the modern unsensational methods of evangelism are as productive of permanent results as the old-time perfervid protracted meetings, overflowing with enthusiasm, and sometimes marked by spectacular conversions of elderly sinners ${ }^{16}$.

\section{THE Usefulness oF SIMPSON COLLEGE}

Through all the vicissitudes Simpson college maintained its high level of usefulness under a series of presidents of whom the most eminent were Charles E. Shelton and John L. Hillman, the last being still with us as president emeritus. By means of various financial campaigns, supplemented by less public solicitations of successive field agents, the material assets were multiplied over six fold-from $\$ 183,000.00$ in 1901 to $\$ 1,150,634.00$ in 1932; burdened by the indebtedness of barely six per cent, and with a productive endowment, affording the management a sense of comfortable security even in the then prevailing depression. Much of the expansion is represented by the great administration center and the Hopper gymnasium, this last the gift of a fortunate alumnus.

A decreased enrollment of a little over a hundred during this period spells no falling off in morale or efficiency; for widespread improvements in educational facilities throughout its patronizing area, eliminated the grade school and preparatory departments. Upspringing new junior colleges in the larger towns cut in on the lower college classes, but the addition of business, normal and musical departments mainly compensated these losses, Simpson's contributions of ministers, missionaries and educators never fell off, besides supplying cultured accessions to secular pursuits. Renewed pro-

\footnotetext{
10It is with profound pleasure that the writer reads of the reawakened interest of all denominations to the tragic state of "open country", and are beginning reoccupation of these neglected fields. In Methodist tactics this often takes form in county seat churches, at one time quite unwilling to release their pastors for "outside" activities, which now are taking over adjacent village and rural congregations, as fertile recruiting grounds for their own personnel, to offset the steady drift cityward from their own ranks.
} 
posals for removal to the Capital city were regularly declined until with improved travel facilities Indianola has become virtually a suburb of Des Moines. Likewise certain efforts to attach some moribund denominational institutions to our educational program have been disapproved, and Simpson college flourishes as the sole purveyor of religious higher education in the southwest quarter of the state, outside of Des Moines.

Another educational development materializing about the middle of the period now under consideration consisted of establishing the Wesley Foundation, for the spiritual oversight of the great volume of students from Methodist homes attending our three great state educational institutions, one of which being at Ames, was distinctively a Des Moines Conference project. Due to the initiative of the Rev. George D. Crissman, during his pastorates at Ames and Boone, liberal minded laymen at these two places were enlisted in purchasing the site now occupied by the Ames Collegiate church, and erecting thereon a temporary structure serving as religious, social and recreational center to such good purpose, that during its first year, out of the quota of 1,135 students of Methodist antecedents enrolled in Iowa State college at that time, fifty-three decisions for Christ were won, and ten candidates pledged for home or foreign missionary work. In 1926 the long over-crowded original building was replaced by the stately Collegiate church, valued, together with the Wesley Foundation edifices, at $\$ 175,000$.00 , having a church membership at dedication of 264 , and conducting classes in religious instruction numbering over 1,200 .

\section{LESS OCCASION FOR DISCIPLINE}

The record of judicial proceedings against offending clergymen given in Section $\mathrm{V}$, is very much shortened in this final chapter, not that there were no occasions of offence, but less conspicuous ways were found for dealing with them. These probably originated in a la- 
mentable case in which a presiding elder, accused of a series of moral lapses, was found mentally unbalanced, committed to a state hospital for treatment and discharged as cured. He was granted the retired relation, took up the duties of night watch in a city business block, but unfortunately suffered fatal injuries in battling a midnight conflagration.

However much this case may have affected procedures, only one instance of expulsion from the ministry and membership of the church marred the records of these last thirty-two years. In several instances wrong doers, on being confronted by conclusive evidence of guilt, chose to avoid publicity by withdrawal under charges, tantamount to trial and expulsion. One brother found guilty of serious reflections upon the business integrity of brother ministers in another conference, was suspended for a year, but subsequently rendered good service in this and another conference. Under complaints of imprudent conduct, one preacher asked for and was granted a location, was employed by the Anti-Saloon league, and after a few years, on withdrawal of the original charges by the complainants, was restored to conference membership, and conducted himself worthily until his decease. A very conspicuous case was that of a pastor who withdrew under charges of embezzling benevolent funds, and almost immediately demanded permission to retract his withdrawal. Said request was decisively rejected in an intensive executive session, the details of which are still mentioned with becoming reserve by participants, even after the lapse of quarter of a century. Bidding adieu to these unpleasant reminiscenses of clerical wrong doings, the writer wishes to say that the sole object of this resume of judicial procedures, is to place in the historical records suitable evidence that the annual review of character and conduct observed in every Methodist Annual Conference neither was nor is an idle gesture, but an austere reality to those who bring reproach upon the ministry of the church. 


\section{NeCROLOGY FOR THE PERIOD}

A necrological review of these seventy-two years yields interesting data relating to ministerial longevity and service. Of seventy-three members of conference deceased during the epoch 1860-1900, almost half, thirtytwo, died in the effective relation, all their ages averaging fifty-two and three-eighths years; the extreme being twenty-nine and eighty-eight. Of 164 deaths in the period 1901-1932, exactly one-fourth were effective at the time of decease; the remainder being supernumerary or retired, the average ages of the entire number being a fraction under sixty-eight years, with age extremes at twenty-seven and ninety-six. That the foregoing increase of life tenure still operates is manifest in the seventy-four deaths of old Des Moines Conference men since 1932, of whom but one was effective; average ages were seventy-eight years, and with the same extremes.

The evaluations of merit accorded representative preachers of the earlier years in Sections IV and V, either upon admission to conference, or at their decease, calls for some appraisal of twentieth century successors; and as space is limited for transcription of obituarial records, selection is made of such as seem suitable types of the whole body. If any names deserving especial tribute have been overlooked it is from absence of personal knowledge of the men, not from conscious underestimation of their worth. As a number of those here registered as passing on were duly characterized in earlier chapters, the date of their departure must here suffice.

Among such were Samuel W. Milligan and John Anderson, who departed this life March 26 and July 17, 1901, charter members of Western Iowa Conference, and long time honored superannuates. But otherwise with James F. Campbell, deceased early in 1902, one of the ablest and latest of the local preacher clergymen received into conference when past middle age. He was reared a Calvinist, and affiliated with Methodism merely 
through lack of a Presbyterian church in his vicinity. The studies for local deacons orders transformed him into an ardent Arminian. Admitted to the itineracy when past fifty, nothing but precarious health hindered his rise to the foremost ranks in the pastorate. His keen observations of human nature and no less devoted study of books gave his preaching a sympathetic yet logical content, productive of sincere repentance and thorough conversion among his hearers. A sense of humor tinged with sarcasm, sometimes cut to the quick, yet permitted full appreciation of whatever promise he could discern in younger and less successful men, and while his genius for retaining friendly ties caused some successors to view with distaste his frequent returns to former charges for weddings and funerals, he always made opportunity for bolstering the prestige of the present incumbent. His superior mentality even amid the shadows of nervous affections, ever provoked the reflection, "What a master of assemblies he might have been, had he entered the ministry in early life!"

Dinsmore Austin's record, deceased just prior to the 1902 conference session, appeared in Section V; likewise that of B. F. W. Cozier, first of the "continuing cabinet" to leave us, who passed away in May of 1903, in Idaho, whither he had removed after retirement. In December of the same year the name of John W. Snodgrass was transferred from the roll of the living to that of the $\operatorname{dead}^{17}$.

Of Samuel Farlow, deceased Nov. 25, 1906; Charles C. Mabee, 1907; Daniel Lamont and George J. Nixon in 1908, and William C. Martin, 1909, we have already spoken at some length, but not of David Shenton, bred an English coal miner, at which task he labored in Jasper county, where he graduated into the itineracy via three

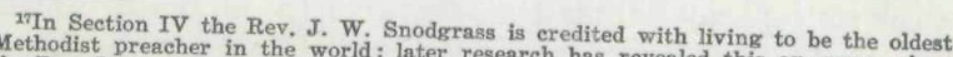
Methodist preacher in the world; later research has revealed this an error, since of Father Snoc Kelley, charter member of Western Iowa Conference, was the senior removal to California many years, and survived him the same length of time. His spective, and occasioned the awarding to decease, took him out of the Iowa perby righted as much as may be possible. 
years activity in the exhorter and local preacher ranks. There he preached for his first year on trial; then under the three and five-year rules of pastoral tenure he served every parish to which appointed the full term permitted. Dignified in appearance and bearing, affable in demeanor, level-headed in judgment, convincing in utterance, he progressed from good places to better; served several prominent churches; filled the post of conference treasurer for a long period, and dying in 1909, left a son, David J., who likewise "obtained a good report" as pastor and district superintendent, and went to join his father while yet in middle life.

David O. Stuart ended his earthly pilgrimage in 1910 , his chief claim to remembrance being the three sons who entered Des Moines Conference; Charles, the youngest, made proof of his ministry in China, where he presided over a district before he became an elder, and obedient to Bishop Fowler's mandate, laid "foundations to last for a thousand years" on the bold river bluffs of Chung King, where they proved their stability under the fiery baptisms of the war years. Thomas McK., previously characterized, fell quietly asleep in May of 1911, while fitting up the grounds of what he expected to be the home of his retirement years. William Abraham had preceded him in January of that year. During the year 1912 , out of a dozen places left vacant on the conference roll, at least six had been filled by men of eminent record, most of whom have been characterized heretofore.

William S. Hooker died January 12; Benjamin F. Miller, after filling a Presiding Eldership with credit, passed away May 22, in the midst of a successful pastorate at Jefferson; Emory Miller, full of years and honor, died July 3 ; Fletcher Brown, given recognition in this section, sustained fatal injuries on October 6, while directing a threshing crew on his Dakota ranch; William T. Smith left us on December 19, and George P. Bennet December 31. In quick succession to these, January 7, 1913, William F. Harned eldest of that famed trio, was gathered 
to his father; September 5, Benjamin Shinn, last lingerer of the charter members, went to join his fellow laborers.

On the next day after W. F. Harned's decease, Samuel N. Matheny terminated a sixty-year ministry, the first twenty-five of which were given to the Methodist Protestant church, where he achieved distinction as an antitobacco champion, adovcate of pensions for aged clergymen, and of admission of women to the ministry. On the acceptance of lay representation by the M. E. church, he transferred his allegiance, and devoted his rather limited abilities to a round of minor charges, never leaving an unpaid debt, nor a doubt of his integrity behind him; and made a record for thrift expressed thusly by a Presiding Elder. "Brother Matheny gets the smallest salaries and lives on them the best of any circuit preacher in my district." Two sons joined Des Moines Conference; the elder preceding his father to the better world, while the other is yet with us, doing faithful work after retirement in what may well be called home missionary fields, by serving poor parishes as "supply pastor;" altogether the family has spent over 150 years in the Methodist ministry and all in Iowa.

July 6, 1915, ended the earthly life of John Wesley Bott, another rare soul who entered the itineracy by the class leader, exhorter, local preacher, route, and for thirty years, on a series of inconspicuous charges, exemplified his favorite text, "I have glorified thee on earth, I have finished the work thou gavest me to do." Retiring rather early in age that he might give better care to an afflicted son, he resumed the work with which he began his career, by seeking out neglected communities and preaching wherever a group would assemble. That autumn took from the widow's rolls the names of two Civil war heroines. Mrs. Artemas Brown shared her patriot husband's flight from Kentucky "three jumps ahead of John Morgan;" while Mrs. Dugald Thompson many a Sunday morning saw her loyal-hearted husband 
ride away on his rounds of a circuit seething with antiUnion sentiment, not certain she would ever look upon him again in life.

That 1915 session heard Isaac M. O'Flyng answer "Here," for the fifty-seventh time to a conference roll call, but ere another such call was made his place knew him no more. A son of the parsonage, converted at seven years of age, he chose dentistry as a profession. $\mathrm{He}$ was given Local Preacher's license at twenty-three, and the same year received on trial by West Virginia Conference. Coming to Iowa in 1868 he was stationed at Sydney, and spent a week getting to Des Moines for conference at the years end, making the trip by lumber wagon, carrying provisions and forage along, crossing bridgeless streams and roadless prairies in true pioneering fashion. His appointments included only minor or at best medium charges, all of which he served with cheerfulness, lightening toilsome labor with quaint Irish drolleries that won friends everywhere. Of him a nonChristian neighbor said, "He minds his own business the best of any preacher I ever saw!"-a tribute truer than intended, for he was warm hearted, companionable and a successful revivalist. Retired after forty-four effective years, he supplied nearby vacant circuits six years longer, always insisting these should be added to his annuity credits, claims to which the embarrassed stewards could only reply, "You ought to have it brother, but its agin' the law."

Andrew Hancox, English born, converted at fourteen, employed as local preacher on the Wesleyan circuits, veteran of the Federal forces in the Civil war, joined Des Moines Conference in 1871 . Thrown into northwest Iowa by division, he soon found his way back, gave us thirty-seven faithful years, and passed on after seven years in retirement. Energetic and successful as a pastor, his judicial temperament often tested and never questioned, was often employed in disciplinary actions affecting ministers and laymen alike. J. T. Hughes 
deceased in 1920, John F. St. Clair, John Harned and Asahel E. Thornbrue have all been previously portrayed, but not British Enoch Hill, who was licensed to preach at twenty, while toiling in the coal pits of Wales; was employed on the Wesleyan circuit under directions of the assistant preacher in charge on this side the ocean, and while very young for grave responsibilities, acted on an arbitration board in labor disputes of seven years standing, affecting 300,000 workers. In America he supplied a Pennsylvania pulpit for a year; joined this conference in 1885; was assigned to a circuit in the then rich coal fields of Moingona; moved up through minor and medium charges to some of higher grade. We associated as stewards for almost twenty years, where I learned to love him like a brother and trusted his judgment above my own. On a November eve of 1922, we laid his body away in Glenwood cemetery, just at sunset, and as Superintendent George D. Crissman reverently intoned Tennyson's "Crossing the Bar," it was almost possible to visualize the flight of that earnest soul, as he "sailed into the fiery splendor, to the Land of the Hereafter."

In 1923 we erased from the widow's roll the names of the last survivors of the noble group who shared the toils, triumphs and trials of the circuit riders who laid and built upon the foundations of Western Iowa Conference. Not far apart in time, Mrs. Benjamin Shinn, aged eighty-nine, and Mrs. Samuel Farlow, aged ninety-two, went to join their husbands in the realms where many must have risen up to call them blessed. Early in 1925 we mourned Fred Harris, an Irish lad, who almost immediately after landing on American soil, enlisted at seventeen in the First Nebraska Infantry; fought in defense of the Union five years; and while yet in that service was converted so thoroughly, as he prayed alone at the foot of a great oak, that on discharge from the army, he dedicated his life to the ministry, and spent his first trial year in Dakota territory, then including what now constitute three great states. Here he erected 
the very first house of worship in all that vast domain, and progressed to some of the more prominent pulpits, besides responsible conference posts. He was highly talented both as preacher and lecturer such as would have fostered conceit in smaller natures; but ever manifested consideration for his juniors in age and rank, as this writer benefited by while serving apprenticeship in pension administration under Fred Harris as chairman of the board. Five days subsequent to his decease, Charles W. Stuart, last of his family, was laid to rest. Retiring early on account of his wife's invalidism, he served Clarinda society as justice of the peace, and while filling this position, relinquished his pension claims in favor of less well provided brethren. And only a month later, sweet-souled William B. Thompson went to live in Heaven not as a stranger, since his entire life on earth had been devoted to a heavenly career.

This same year another tie with the remote past was broken. Much was said in Section V, of Mahlon D. Collins, but common fairness demands mention of the gracious lady, who coming with her Quaker parents to northwestern Iowa at fifteen years, two years later was united in marriage with the frontier merchant and magistrate, whose changeful career she joyfully shared more than half a century. Driven by the Spirit Lake horrors into tiny Fort Dodge for shelter, she very soon after braved the savage perils of the great plains in the Pike's Peak gold rush; faced with scarcely lass savage terrors of the Denver mining camp, stained with seven murders during the Fourth of July revelries; and in the absence or ordinary comforts refused the barter of her cook stove for the 160 acres whereon in after years was located the Denver Union Railway depot. Returning to Iowa and the calling of her husband into military service, she cared for her little flock single handed. Then, in quick transition, she went with him into the Methodist ministry, travelling Denison circuit, where by change of boundaries came among us, and rose step by step, the good wife adorning every post held by the husband, from 
lowest to highest, her gracious personality and angelic disposition contributing largely to their mutual success. Deprived of her pension rights, as the law then stood, by his transfer to a Texas conference just a few months prior to his decease, this conference honored itself by a unanimous invitation for Mrs. Collins to take her place on our widow's roll.

1929 took from us William E. Hamilton, previously commemorated, and very appropriately, during the last year of its separate existence, Des Moines Conference mourned over two more of the old guard, whose ministry began simultaneously, ran parallel for half a century, and terminated within fifteen days of each other. William H. Shipman's keen sense of ministerial rectitude, previously mentioned, will bear the additional post-mortem tribute paid him by District Superintendent Jay Kirkendall, now deceased: "Had I ever chanced to enter the conference room during a character discussion of which I knew nothing, I would have instinctively sided with Will Shipman against the most eminent opponent in the body." The younger Shipman, having made full proof of his ministry during his father's lifetime, has rated among the leaders of the larger body ever since the reunion of 1932. Having heretofore evaluated William Stevenson it is only necessary to add here, that after a brief separation at the River's brink, he and his estimable companion, herself a model of good words and works, joined hands again on the farther Shore.

A few more Des Moines Conference worthies' passing has occurred more recently. Nothing but life-long impairment of vision prevented William F. Bartholomew from attaining the highest place in Methodism. Sightless from birth, at seven he received the scantiest illumination of his darkness from the then extremely rare and perilious removal of cataracts, enabling him to enter school only at fourteen, and regarless of this belated start, De Pauw University awarded him his A.B. at twenty-two, and its D. D. much later in life than merited. 
Entering the ministry in Indiana, he began his Iowa career on one of the pioneer circuits, advanced speedily to station preacher status, and filled some of the foremost pulpits, usually for the full pastoral term then allowed. A poet of great merit, and a valued contributor to church periodicals, his pulpit talents may be expressed by the tribute paid him while yet living, by one of the very greatest ministerial orators this state ever produced. The writer while conversing on men and things with the famous Rev. Frank M. Evans, chanced to relate the incident when W. F. Bartholomew, on finding he was assigned to preach the conference missionary sermon on Sunday night in the pulpit occupied by Bishop Goodsell in the morning and Bishop Taylor in the afternoon, exclaimed despairingly: "Two bishops ahead of me the same day! What can the man do that cometh after the king?" "Do?" blurted Frank M. Evans, "Frank Bartholomew could preach all around either of those men, the best day they ever saw!" Mrs. Bartholomew whose eyes served both of them during their lives together, and doubly so in his final epoch of total blindness, survived him by four years, dying in 1937. 1933 had also sounded taps for Jesse B. Bartley, last wearer of the G. A. R. button among our number. In the last month of 1934, and lacking but three days of his seventyfifth anniversary, Edmund M. Holmes, having taken the retired relation but a short time previously, slept with his father and grandfather, leaving his son Merrill to carry on the family tradition a generation longer.

Moving forward to 1939 we record the passing away of William Christie Smith and wife, she in June and he in October. We have paid them tribute earlier and pause only to note how fitting it was that lives, so much of which were spent in each others society, should not long remain apart.

On January 24, 1946, Amos E. Griffith was released from more than a year of suffering from a grievous accident and went to join the excellent companion long 
awaiting his coming "where they count not time by years." Recognition of the public services of both these excellent people has been already attempted, but the writer cannot forbear expressing a little of the personal regard always entertained for Amos E. Griffith. He was chairman of the board of examiners when I was admitted on trial, and gave me the highest grade in a class of which I was the only non-collegiate; a distinction then meaning far more than can now be appreciated. He rated me well up on the list during the succeeding four years course, and had a word of encouragement in every experience. Our associations were always friendly, and his going leaves a lonely spot in my heart. Dr. Griffith was absolutely a product of the old Des Moines Conference, born, reared, educated, employed, married and buried within its bounds. For three years preceding his decease he was its senior surviving member, being received on trial in 1882. Albert H. Rusk, who came by transfer two or three years later, followed him in less than three months, and was the very last of the company assembled on a certain September morning of 1887 when I first heard a conference of Methodist preachers lift the refrains of holy song; so that with a little adaptation Whittier's lament is mine: "Henceforward listen as I will, the voices of that band are still; Look where I will, the wide world o'er, Those smiling faces shine no more! But Love will dream and Faith will trust, that sometime, somewhere, meet we must."

\section{Elevated to District HONORS}

No individual appraisal of any now living is contemplated in this closing section, aside from a brief resume of those assigned to district supervision during this epoch. Those of our old fellowship thus elevated since 1932 (and the Iowa-Des Moines cabinet has at times been composed of such), must await their fame at the hands of some future chronicler. Likewise some, once of us, who found elsewhere the honors not realized here is evidenced by the fact that at no very distant date, the Nebraska cabinet, was half-filled at one time with Des 
Moines Conference products. One exception to this rule may be allowed in the case of Frank Bean, who after a highly worthy district record here, attained similar distinction in northwest Iowa.

Of thirty men appointed presiding elder or district superintendent in the period 1900-1932, only nine names remain on our rolls at the time this is written, and two of them began their ministry prior to 1900 . Willis $\mathrm{H}$. Cable in 1893 and Fred N. Willis in 1896, both now on the retired list, along with Ezekiel A. Moore, Melvin R. Talley and Walter A. Morgan; while Frederic C. Edwards, Mearl A. Gable, Raymond M. Shipman, and Charles M. Edmondson, are rendering effective pastoral service in the higher grades of appointments. Seven of the nine entered the ministry in Des Moines Conference. Dr. Edwards spent his first fourteen years in Iowa Conference, and the merger merely brought his native heath back under his feet. Fred Willis, the one importation in the group, rode northwest Kansas circuits six years, gave three more to an Upper Iowa charge, and then "going on to perfection," as a good Methodist should, came to Des Moines Conference.

Among the former district executives of this era, whose names now are carried only on Conference Necrological rolls, there are another nine who have been characterized at greater or less length on preceding pages, leaving yet unnamed a round dozen whom the appointing powers considered worthy and well qualified for sub-episcopal rank: William G. Hohenshelt, Benjamin F. Miller, Elmer E. Ilgenfritz, George W. L. Brown, Charles L. Baxter, Albert H. Collins, Allen A. Thompson, Reuben E. Shaw, Anthony E. Slothower, S. Grant Lewis, James M. Williams and Arthur Atack. The first of this list, the writer, as far as he knew then or since, was the first to mention as a suitable successor to a retiring presiding elder, back at the century's beginning; E. E. Ilgenfritz enjoyed the proud distinction of nomination by a former parishioner, who had become secretary of 
the U. S. treasury; A. A. Thompson and R. E. Shaw, each served two terms in the district office, and as it chanced, on the same districts, Boone and Chariton; and Arthur Atack, a transfer from Nebraska, with ambition fully satisfied by one year in the office, moved on into Dakota, and there passed to his eternal reward. "One star differeth from another star in glory," and so of these men, some were able preachers, others efficient executives, still others were both; all, as much as in them lay, promoted the welfare both of the church and Kingdom, alike in pastoral and district incumbency, and best of all, none ever brought reproach on either the church or the cause of Christ.

\section{REMOVAL OF BOUNDARY DIVISIONS}

Let us now make note the process by which the Methodists of southern Iowa, severed by mutual agreement in 1860, were reunited as one body in 1932. In Sections II and III was related the dissatisfaction arising over fixing the dividing line between the two sections; a feeling deepened into intense regret east of the boundary that they should have confined themselves within about one-sixth of the state, once all their own, as they witnessed the rapid expansion of the younger conferences carved out of the areas once considered so unpromising. This feeling which after the creation of Northwest Iowa Conference in 1872, expressed itself in efforts to obtain complete realignment of all conference boundaries in Iowa. The proposal was resisted so strenuously by all the other units, that it finally settled down into a frequently renewed request for the ceding of a liberal margin off the eastern front of Des Moines Conference. On this line the contest was fought out until well within this century, when with improvement of communications facilities, the proposition took the form of removing the boundary altogether.

As might have been expected, this solution encountered objections too numerous for complete mention. The increase of clerical moving expenses by reason of the 
greater distances, the difficulties attendant on providing conference entertainment for the enlarged body, the rival interests of the two colleges, and the readjustment of diverse pension administrations, were but a few of the most outstanding obstacles to negotiations, renewed quadrennially by Iowa Conference, prior to every session of the denominational governing body.

Such admirable persistence at last materialized in a memorial passed by a very moderate majority in Iowa Conference of 1923, but negatived decisively by the laymen of that body; it was submitted to Des Moines Conference by a commission from the former body, and obtained a majority of one, in a light ballot, while our laymen good naturedly remarked: "If that is what the preachers want, let them have it," and passed it. The General Conference of the ensuing year granted permission for the two bodies to lift the barrier at pleasure, which Iowa, in September 1924, voted by a six-elevenths majority. On learning of the action Des Moines Conference prudently resolved to withhold approval of the measure until the eastern brethren knew their own minds a little better. Four years later the two bodies joined in creating a commission for thorough study of the question in all its bearings from which evolved the plan, which, sanctioned by the General Conference of 1932, resulted in final consummation of the union in September that year. It is only fair to add that several proponents of the merger have in the meantime expressed regret at its accomplishment, but with an agitation under way to unite the entire state in one conference, it is highly unlikely that any backward steps will ever win consideration.

\section{SERVICE CROWNED WITH HONOR}

With the conclusion of this chronicle some reader might very properly interpose the query, "And what have you to say of the laity, without whose backing your clergymen, from the most talented bishop to the humblest ex- 
horter, would have had no better success than could a general and his staff in conducting a campaign unaided by a valorous rank and file?"

To this just criticism the writer can state that not only lack of space in such a series, but also absence of sufficient personal knowledge of enough individuals for adequate portrayal of a vast company, including governors of the state, congressmen, supreme court justices, a presidential candidate (third party), merchants, bankers, attorneys, journalists, educators, farmers, mechanics, day laborers and housewives in all these walks of life. Highly appropriate as such narration would be in a general history, he will endeavor to substitute therefor, an evaluation of a single household known to him from early boyhood, as depicting the moral and spiritual excellences existing in almost every community within the era and area treated in these articles.

In the cherished scrap book previously mentioned, the obituarial portrait of the Rev. James M. Buckley, renowned journal, orator and statesman of Methodism, is crowned by the pencilled legend from Longfellow: "The Gaunt Figure of the Old Field Marshall." Close by is pasted the photogravure of two plain, elderly people, enwreathed with the Kiplingesque quotation, "The backbone of the Service is the Non-Commissioned Man," for such were these two during nearly seventy years of life spent together in one community.

Isaac Talley and Nancy Keller were youthful charter members of Bethel class, in Ringgold county. Married on coming to maturity, they established a home wherein Godliness reigned, and ten children were brought up "in the nurture and admonition of the Lord." Answering the nation's call in her hour of peril, Isaac enlisted in Company M, Third Iowa cavalry, and gave eighteen months of faithful service, facing the dangers of battle with the same intelligent coolness characterizing his dis- 
charge of all civilian duties. Meantime Nancy kept the home fires burning and food crops growing, along with caring for the earliest of her brood ${ }^{18}$.

With the division of the Adam Talley estate, Isaac received the old homestead, which he cultivated as joint tenant with the Almighty, whose counsel and blessing he sought for every field planted, and crop harvested, and to whom he rendered due return of all the increase. As Bethel church and cemetery were located on this farm, only a short distance from the residence, Mr. Talley did far more than his share as caretaker of both, besides filling the posts of Sunday school teacher, secretary, treasurer, chorister and superintendent (often handling two or more places at once). Also he served the church as class leader, steward, trustee, recording secretary, and if there were any other lay offices, aside from local preacher, he held them at some time or other. In like manner, Mrs. Talley occupied every position accorded to Methodist womanhood, and made her home a center of hospitality so wide-spread that the most rigid

18In Section II of this history, the Adam Talley elass, organized in 1856, is credited with erecting the first M. E. Church in Ringgold county, in the late 1860's : which I could easily accept since on May 21, 1870, passing through Mt. Ayr the first time, I saw the scaffolding round the new Methodist church in that town and the carpenters busy in the construction. But, later that summer I attended church and Sunday school in old Bethel, which I remember even then showed such marks of use as growing boyhood is prone to inflict upon public gathering placecs. But, while Section II was in the press, and the author under the surgeon's care. a letter from my boyhood friend, now deceased, Randolph S. Beall, of Mount Ayr, gave the following information, best conveyed by transcription of the original:

"Feb. 1, 1944. Dear Ray Harvey: Thank you for 'Reopening a Closed Chapter, in the January ANNALS OF IowA. Just within the last ten days I was surprised to learn that there was a Methodist church building in Jefferson township. (Ringgold County), erected in 1855 (nearly 15 years before the Mount Ayr or Bethel churches were erected), which stood there until 1878. Mr. Quinn, a native of Jefferson township, who has been away from here for more than half a century, and who now lives in northwest Wyoming, told me about it. I have verified it from a number of sources. It was in Sec. 15-70-30, one mile east of center of Jefferson township. Joe Irving, who was in the church when a boy, tells me it was a small building, of native lumber, with native lumber slabs for seats.

Mr. Quinn, who was here but a few days, was seeing the board of supervisors to protest against an old cemetery acre in which his ancestors are buried being
plowed up. As ever, Your Friend: RANDOLPH."

Erected in 1855, this must have been the result of the Rev. W. C. Williams' work, first conference appointee to the Ringgold and Union county field. The foregoing communication arriving too late for insertion in Section II, end the writer not being in circulation at that or some time afterward, this correction has of necessity awaited this late appearance. Without doubt many other such incidents might be gleaned from the territory covered in these sketches, were time and information available, but having done the best possible under existing circumstances, this historian hereby resigns his task with best wishes and God speed to any succeeding research artist who may feel capable of improving the imperfections of these "few feeble efforts." 
economy and intense industry must have been required to make ends meet, especially during the "hard times" marking the seventies and nineties of the last century.

That the home was "preachers' boarding house" for all the itinerants goes without saying. In it two young theologues tarrying as roomers, received every possible measure of encouragement in pursuing their clerical training; scarce a Sunday passed without welcoming youngsters to visit their own group, always to the betterment of at least the guests, as is gratefully remembered by one who was so often bidden, "Come over for dinner," after morning services at dear old Bethel. For, in that home circulated an atmosphere suggested by Isaac Talley's response to the cynical remark that all married people had their quarrels, made by a member of an unhappy family. Said this good man, "You must not think that way; my wife and I have never had a quarrel; not but what we have our differences, but manage them without bad feelings!"

Every financial need of the church received from the Talley's liberal, most liberal support, even to the point of insisting that their class, being the strongest on the rural circuit of which they were part, should make up any deficit occuring in the weaker points. When Bethel class moved into Goshen village on the railroad, and that in turn migrated to Diagonal town, the Talley's went along, helping rear both church buildings, and participating in all religious activities with the zeal of earlier life.

Once during these later years, on being asked by the writer of the well-being of the church, Mr. Talley replied, rather sadly, "Well, we are now right about where we have been so often before, when just as we thought we had a bunch of young people ready to take over the load, they have gone out into wider fields of usefulness, and we had to fall back on the 'teen aged youngsters to help carry the burden." This called forth as the most suitable response, "And what higher honor can the Good 
Lord bestow upon any set of folks than that of training up five or six successive groups of young people to carry the Good Tidings abroad?" It was a fulfillment of the ancient promise, "They shall bring forth fruit in old age," and as their personal share in this service to humanity, two of the daughters of that home married ministers; their youngest son, returning from U. S. army medical service in World War I, established an excellent practice in a northeastern county seat town; and the brother next older, served Des Moines Conference fortyfour fruitful years as pastor, secretary and district superintendent, now enjoying the honorable repose of the retired relation.

On the tombstone marking the burial place of these worthy people might well be inscribed the Davidic elegy, "Lovely in their lives, in death they were not divided." For, within a few hours of each other, they took leave of the world they had so much helped make better, for a better world prepared for all such as they. While such households abide among us, Methodism surely cannot fail to provide her share of the saving salt that preserves humanity from corruption, and points the way to higher levels of goodness.

\section{THE PRIVILEGED PEOPLE OF THE WORLD}

Dr. Marvin O. Sansbury: We Americans have so much to be thankful for that not one of us knows where to begin in the counting of our blessings. Surely, we are the privileged people of the world. Naturally, we have many problems these days, but we shall solve them, and I believe that we shall go on from year to year building a more peaceful world because the spirit of good Americans-and they are certainly in the majority -is one of gratitude. We love our land, our homes, our churches, our schools, and our common sense coupled with a spirit of good will, neighborliness and thankfulness will solve all of our problems. 
Copyright of Annals of Iowa is the property of State of Iowa, by \& through the State Historical Society of Iowa and its content may not be copied or emailed to multiple sites or posted to a listserv without the copyright holder's express written permission. However, users may print, download, or email articles for individual use. 